\title{
Translation Laboratory: Oskar Pastior's Applied Translation Research
}

\author{
Thomas Strässle
}

\begin{abstract}
:
In his intonations to a poem by Charles Baudelaire, which appeared in 2002 under the title o du roher iasmin, Oskar Pastior conducts a piece of applied translation research. He meets the challenges of literary translation, as they are most prominently shown in lyrics, in a translation laboratory in which, in 43 attempts, the different sides of the Baudelaire poem are set out and examined. The act of translating is methodically segmented and explored regarding its latitude, and it is systematically and polyperspectively put in reference to the many different aspects of the body of language. By serialising the individual attempts, the literary text gains an argumentative structure that makes it readable as artistic research: it produces aesthetic knowledge in artistic practice.
\end{abstract}

How should a poem be translated? Or more precisely: What aspects of it can be translated at all? The horizon of meaning it creates? The rhythm that carries it? The structures that determine it? The timbres that form its body of sound? The shape its letters create? Or none of these aspects? And therefore some entirely different aspects? Or preferably all of them and many more? The only certainty is that the problems that arise in the process of every literary translation are most prominent when dealing with lyrical texts.

Bertolt Brecht advised concentration. In a lyric-theoretical comment on the translatability of poems, he wrote: "Poems usually get damaged most strongly while being translated into another language through the effort of translating too much." Instead, one should 'be content' with the translation of the writer's attitude towards language by imitating certain aspects of the work, "not more," as Brecht was swift to point out: "The occasion for this imitation must not necessarily be prescribed by the original."2 Brecht's translation maxim does not

1 Bertolt Brecht, "Die Übersetzbarkeit von Gedichten" (1935), in: Schriften zur Literatur und Kunst 2 (= Gesammelte Werke 19), ed. by Suhrkamp in cooperation with Elisabeth Hauptmann. Frankfurt am Main: Suhrkamp, 1967, p. 404.

2 Ibid. 
only aim for the translation's autonomy of the original - the translation can never be a 'copy' of it - but also for a reduction of the means: one should not 'damage' a poem by trying to transfer 'too much'. Too much at the same time, as could be added, but one should, by implication, deliberately limit oneself when translating.

This provides the theoretical possibility of making use of a serial technique when translating literary texts. It counters the danger of 'too much' not by translating the poem in a singular act while dealing with as many aspects as possible, as it is usually done, but by undertaking several diverse attempts, each focussing on one very particular aspect at a time. One of the most convincing attempts to translate poetry follows the strategy of Oskar Pastior's 2002 'translations' of Baudelaire. It is a piece of applied translational research, an experimental translation laboratory, in which the process of translating is segmented and explored in terms of its latitude.

\section{Oulipotic Concept of Translation}

To understand this technique, one must understand the literary-historical context of Pastior's interaction with Baudelaire's work. Oskar Pastior belonged to Oulipo, a circle of authors that was founded in 1960 and still exists today (Oulipo is an acronym of Ouvroir de littérature potentielle, i.e. Workshop for Potential Literature). The association transgressed the boundaries of the so-called 'national literatures,' and it not only consisted of writers but also of writing mathematicians, linguists, chess theorists, and architects. Amongst its members were personalities like François Le Lionnais, Raymond Queneau, Georges Perec, Italo Calvino, and Harry Mathews. ${ }^{3}$

The goal of this group is to replace the mystifying concept of 'inspiration' with the term 'organisation' in the sense "that a particular information entered is treated in such a way that all possibilities of this information are being systematically looked at in the light of a model," as Queneau stated. ${ }^{4}$ This also explains the concept of 'potentiality,' which the group bears in its name; it is about the greatest possible emancipation of the text from the subject or the subjectivity of the author in favour of a mathematical autonomy or momentum

3 For an overview about the history and aesthetics of the group Oulipo, see Jacques Bens, $\mathrm{Ge}$ nèse de l'Oulipo 1960-1963. Bordeaux Cedex: Castor Astral, 2005, as well as Hervé Le Tellier, Esthétique de l'Oulipo. Bordeaux Cedex: Castor Astral, 2006.

4 Cited in Klaus Ferentschik, 'Pataphysik - Versuchung des Geistes. Die 'Pataphysik \& das Collège de 'Pataphysique: Definitionen, Dokumente, Illustrationen. Berlin: Matthes \& Seitz, 2006, p. 210. 
corresponding to the linguistic material. The aim is to systematically explore the features of a language within its range of possibilities, to run through the differences that produce meaning, to prioritise the open possibilities of language over factual linguistic practices. ${ }^{5}$

Such an elementary particle poetics sees itself as a radical amimetic work on the signifier: on the signifier in its phonetic and graphemic qualities and phenomenalities, on textual molecules such as letters, syllables, and words, on structural elements such as combinatorics, syntax, and grammar-as work on the materiality of language. This 'work' (i.e. ouvroir, workshop) follows a method. Moreover, it has an oulipotic shibboleth called "contrainte," that is, coercion, obligation, restriction. ${ }^{6}$ It represents the rules of the game, generative patterns that unleash potencies regarding its text genesis, and lead to an autopoiesis of textures, formal, and material contraintes pour la composition des textes littéraires.

Insofar as this écriture sous contrainte carries its principle in itself and generates texts from it, it leads to a rencontre interne, to an encounter of the language with itself. Because, in the end, an oulipotical text addresses only the entanglements of its limitations: "Un texte écrit suivant une contrainte parle de cette contrainte," as Jacques Roubaud, another member of the group, stated. ${ }^{7}$ As these contraintes refer to language and are, in turn, linguistic, an oulipotic text can be read as one in which the language reads itself, as becomes clear, particularly but not only from some of the contraintes préférées of the Oulipotes. For example, from anagrams, which allow a language to be read through the materiality of its letters, or palindromes, in which it can be read in reverse. The procedure is the texture, the approach is the text. ${ }^{8}$ Oskar Pastior put it in the shortest possible form: "The 'how' of the procedure turns out to be the ontological 'that': that text be there. Conjunctive, virtual, potential. Oulipo sends its regards." ${ }^{n}$

5 See also Uwe Schleypen, Schreiben aus dem Nichts. Gegenwartsliteratur und Mathematikdas Ouvroir de littérature potentielle. Munich: Meidenbauer, 2004, p. 406.

6 On the oulipotic self-declaration of the term contrainte, see also Oulipo, ed. by the ADPF (L'Association pour la diffusion de la pensée française). Paris: ADPF Publications, 2005, pp. 22-23. On the rhetoricity of the contrainte, see also Christelle Reggiani, Rhétoriques de la contrainte. Georges Perec - l'Oulipo. Saint-Pierre-du-Mont Cedex: Éditions InterUniversitaires, 1999 .

7 Cited in Clemens Arts, Oulipo et Tel Quel.Jeux formels et contraintes génératrices. Ridderkerk: Offsetdrukkerij Ridderprint, 1999, p. 98.

8 See also Oskar Pastior, "Petrarca, und andere Versuchsanordnungen," in: Axel Gellhaus et al., eds., Die Genese literarischer Texte. Modelle und Analysen. Würzburg: Königshausen \& Neumann, 1994, pp. 257-286: here pp. 277-279.

9 Pastior (1994), Petrarca, p. 286. 
If in the oulipotic experimental procedure of an écriture sous contrainte language always reads itself, then this also means that it always translates itself. This applies not only within the respective language but also in the interaction with other languages.

However, the question is what this means for an "oulipotic concept of translation," for a traduction sous contrainte(s) considered as an artistically researching, methodical technique of literary translation. An oulipotic translation concept had not been established in practice before $2000,{ }^{10}$ and, in theory, not to this day. In his 1995 Vienna poetics lecture "On Dealing with Texts," Pastior complained:

Let's exaggerate (which we do anyway) by reducing our language (which we do anyway) — so let's play dumb and say: Oulipo or not, text-generative methods and translating exclude each other. Just move in different dimensions ... The process of 'from one language to another' is not yet a rule of the game ... - but Oulipo, the potential workshop, could, of course, find, develop, and deduce further reduction mechanisms also in this direction. ${ }^{11}$

At the same time, Pastior was fundamentally sceptical towards the concept of 'translation.' "Translating is the wrong word for a process that does not exist." 12 He emphasised this in his Vienna poetics lecture several times and repeated it frequently in other places:

Because translation (and not only what the word 'translation' suggests) is, strictly speaking, not possible. But since the word exists, I, too, conventionally use it as a coin and again and again fall for the fallacy that there was something like a countervalue... Only texts that are not language, and are therefore no texts, can be translated. ${ }^{13}$

10 Grazziella Predoiu tried to read Pastior's 33 Gedichte on Petrarca from 1983 as an "oulipotic translation, as transplantations" and to examine them "in the context of oulipotic exercises in style," yet the four "principles" she saw in the work are a) lack knowledge of the "original" language, b) dissolution of Petrarca's metaphors into discursive syntax, c) total neglect of the sonnet scheme in favour of simple linearity with prosaic blocks as the characteristic style, and d) elimination of a historicising inhibition threshold. These, due to their diffused general nature, do not count as specifically oulipotic contraintes (see Grazziella Predoiu, Sinn-Freiheit und Sinn-Anarchie. Zum Werk Oskar Pastiors. Frankfurt am Main et al.: Peter Lang, 2004, p. 187 and pp. 191-192).

11 Oskar Pastior, "Vom Umgang in Texten," in: manuskripte 35:128 (1995), pp. 20-47: here p. 45.

12 Pastior (1995), Umgang, p. 39 (again, see also p. 42).

13 Pastior (1995), Umgang, pp. 39-42. 
The fact that a translation is "strictly speaking not possible" - which can only be meant in the conventional sense-applies only to an outdated concept of 'translation' in which a text transgresses a more or less explicitly drawn dividing line between two languages from one side to the other-with a lunge to the transcendental signified, which is necessarily a step into the void. Pastior immediately clarified: "If there is no translation, then every so-called translation is a special case of autonomous writing." ${ }^{.14}$

\section{Translating as Intonation}

His own "special cases of autonomous writing" of a Baudelaire poem, which were published seven years after the Vienna poetics lecture, Pastior consequently did not call 'translations' but 'intonations'. Not intonations 'of' a or 'on' a Baudelaire poem, but intonations 'to': 43 intonations to 'Harmony du soir' by charles baudelaire, as it says in the subtitle. Much more than an 'of' or an 'on' would be able to, the 'to' establishes a distance between the texts. At the same time, it brings them into a relationship of reciprocal reflection: the 'to' designates the white centre, towards which the texts move from both sides and where that "encounter with the boundaries" — which cannot be drawn-takes place as an "illusion of knowing and learning," as Pastior described the act of translating in the early eighties. ${ }^{15}$

He understood his intonations as attempts "to aim for Baudelaire's textfrom a limited (and also limiting) angle of material strategies of arrangement and localisation respectively," as "approaches, inevitably not on straight stretches," as "gradually feeling one's way to a yet non-existent figure whose details are perhaps already oddly outlined."16 The term 'intonation' is, above all, of a phonetic and musical nature and means striking up, making sound, or pitch movement. In a wider sense, it stands for the (as 'pure' as possible) harmonisation of a variety of sounds, tones, voices, thus representing a state of mood and in any case refers to something that has not just been repealed within the medium of writing. Accordingly, the interferences between Baudelaire's text and Pastior can be read phonetically, and, in particular, musically: as an intonation of a text's tones, its voices, sounds to each other.

\footnotetext{
14 Pastior (1995), Umgang, p. 39.

15 Oskar Pastior, "Vom geknickten Umgang mit Texten wie Personen," in: Sprache im technischen Zeitalter 86 (1983), pp. 178-183: here p. 181.

16 Oskar Pastior, o du roher iasmin. 43 intonationen zu 'Harmonie du soir' von charles baudelaire. Weil am Rhein et al.: Engeler, 2002, p. 64.
} 
Pastior's 'intonations' to Baudelaire, however, do not begin with the poem Harmonie du soir, which they incessantly 'aim at' in 43 attempts, and whose anagram gives the title $o$ du roher iasmin, but with the name of the author himself: 'Baudelaire' or 'Charles Baudelaire.' Hence it is with precisely the linguistic special case of a proper name, which, as Derrida wrote, "remains forever untranslatable" and "does not strictly belong, for the same reason as the other words, to the language, to the system of the language, be it translated or translating."17 Pastior intoned the proper name by deconstructing it, which, in this case, means by anagrammatically liquefying it. The letter material of the name 'Baudelaire' is 'translated' into a cascade of anagrams, which, in German, partially bear a meaning. They are "findings, which obtain significance,"18 as Pastior himself would say. From 'Baudelaire', for example, he derived adriabeule, idealbauer, aber du laie, debile aura - which, in morphological, lexical, and grammatical terms, can be attributed to German but also to French and English. Or they may merely imitate these languages (such as rabe die lau, barel adieu, dealer baiu), or seem to elude any assignability (e.g. leda eurabi, baude aleri, etc.). A comparable process can be observed in the second poem, where 'Charles Baudelaire' serves as text material. Decisive in this overture is less the playful-linguistic decomposition and recomposition or the resulting forms, but rather what happens in them: the deconstruction of the author's authority in the context of a reorganisation or individual reading of the linguistic material according to the anagrammatic contrainte.

Being detached from its auctorial ascription in such a way, the language material of Harmonie du soir is processed in the oulipotic translation laboratory over and over again, and being intoned again and again. The anagrammatic method, which also captures the work title Les fleurs du mal and the section title Spleen et idéal, as well as the poem Harmonie du soir itself-anagrammated line by line-is only one method among many. Pastior brought up a whole arsenal of oulipotic contraintes to intonatingly explore Baudelaire's language material. I cannot deepen everything here, but I will select some examples to create a resonating body that will gradually build its sound from these textual interferences.

\footnotetext{
17 Jacques Derrida, "Des Tours de Babel," translated by Joseph F. Graham, in: Joseph F. Graham, ed., Difference in Translation. Ithaca, NY, London: Cornell University Press, 1985, pp. 165-205: here p. 171. 


\section{Segment as a Method}

The first type of intonation does not, unlike the anagrams, refer to the Letternleib, the shape of the Baudelaire poem, but rather to its Lautleib, its sounds, involving a radical deletion of all semantics and only obliged to the material phonetics. For example, what Pastior described as "surface translation," which is also a contrainte, represents the attempt to orient oneself solely on the individual sound, on the texture, and hence, in many respects, on the intonation of the French text as it is being intonated during the act of translating, and to 'transfer' these aspects to German, where they are re-morphologised and thus re-semanticised. This is demonstrated in the example of the first four verses of Baudelaire's poem:

Voici venir les temps où vibrant sur sa tige

Chaque fleur s'évapore ainsi qu'un encensoir

becomes

wo saß sie wenn ihr [voici venir] gang \& viehbrands ur attische [vibrant sur sa tige]

schlackenflöhe [chaque fleur] aus poren des einsickernden zensors [s'évapore ainsi qu'un encensoir]. ${ }^{19}$

This 'translation' is blind insofar as the eye does not matter. The ear becomes the sole translation organ. However, by way of the pitch movement, the sound spectrum of the Baudelairian lines does not dissolve into an amorphous mass of language material. Instead it integrates with the linguistic pattern of the other grammar-in this case, German.

A similar and yet entirely different process can be observed in what can be referred to as consonantising or vocalising: the transmission of the source text's consonant or vocal linearities into German. In consonantising, "Harmonie du soir" becomes - think of Baudelaire's fragrant flowers-an "aromen-dossier"; the verse "Voici venir les temps où vibrant sur sa tige" becomes "vesuv - nur alte mäuse wabern so rosa o tasche," etc. Whereby, here also, the ear is the sole translation organ insofar as it does not detect what the eye would see (in the not-yet-intonated text). A French 'c' sounds like a German 's,' which allows " $v o$ ici venir" to become "vesuv - nur." The 'p' in the French "temps" is silent and

19 Pastior (2002), roher iasmin, p. 16 and p. 23. 
therefore must not appear when transferred into German. And the ' $\mathrm{g}$ ' in "tige" sounds like the German - however unvoiced-'sch' ("tasche"), etc. ${ }^{20}$ The phonocentrism Pastior applied, which, as shown before, is by no means a general one, is most clearly manifested in the palindrome. For example, in yet another place, he reads the letter " $\mathrm{z}$ " - phonetically written as a 'ts' - in the palindromic sense, like 'st' (as in, e.g., "zaren"|“"ne rast"). ${ }^{21}$

The vocalising principles are comparable to those of the consonantising, yet Pastior varied this type of intonation to an incomparably more considerable extent. Not only as a "vocalising that reduces," as is merely applicable to the three audible vowels a-o-i of the word harmonie-hence the harmonie/harmony vowels or vowel harmonies - nor as a "palindroming of vowels," which brings these very vowels into an endless game of shifts that reflect themselves yet again. He also varied this type by vocalising the entire text of the poem, not merely by changing the consonants around the vowel-order in Baudelaire's poem, but by changing the internal structure of the vowels in Harmonie du soir according to the alphabetically ordered basic schema 'a-e-i-o-u,' and moving it backwards four times by one position, respectively, in four runs per every single line of the poem. This can be demonstrated in the title line: The phonetic constellation of the vowels in Harmonie du soir-'a-o-i-u-o-a' - shifts according to the basic alphabetic schema 'a-e-i-o-u' to the constellation ' $\mathrm{e}-\mathrm{u}-\mathrm{o}^{22}-\mathrm{a}-\mathrm{u}-\mathrm{e}$ ' (deputat - statue). After that it shifts to the vowel constellation 'i-a-u-e-a-i' (insalubre magie), which subsequently evolves into 'o-e-a-i-e-o' (monegassipeon) and eventually into 'u-i-e-o-i-u' (mulinee dos piú), after which, according to the basic schema, 'a-o-i-u-o-a' (Harmonie du soir) would have to follow again. ${ }^{23}$

I am refraining from demonstrating the concept in all sixteen verses of the poem. But what needs to be pointed out is that in the game of endless vowel shift (because after it has been shifted five times including the source text, the game can start over), not merely the internal sounds of Baudelaire's poem resonate. It is their internal structure itself, which gets abstracted by an infinite number of shifts. The only thing transported and transposed in these shifts is the constellation of vowels, which in turn are completely potentialised.

This is a form of the traduction sous contrainte that not only radically rejects all semantics but also causes a splitting of linguistic material.

20 Pastior (2002), roher iasmin, p. 32.

21 Oskar Pastior, KopfnußJanuskopf. Gedichte in Palindromen. Munich, Vienna: Hanser, 1990, p. 145 .

22 In the first shift, a mistake slipped into the third vowel: The a-o-i-u-o-a of Harmonie $d u$ soir should actually turn into e-u-o-a-u-e - and not e-u- $a$-a-u-e as in deputat - statue (see Pastior [2002], roher iasmin, p. 33).

23 Pastior (2002), roher iasmin, pp. 33-36. 
Pastior also made some semantic transmissions, altogether obeying the rules of an oulipotic contrainte as, e.g., "semantically 'opposite," or "semantically 'lean." Using the last 'case' as an example exposes a 'lean' version of Baudelaire's Abendharmonie:
stengel vibrierend
diverse ausdünstungen
klangwolke duftwolke
schwindeltaumeldrängel
diverse ausdünstungen
es quengelt die geige
schwindeltaumeldrängel
firmament firmament
es quengelt die geige
man ist überfordert
firmament firmament
sonnenuntergangster
man ist überfordert
brunnenschwengel pumpt
sonnenuntergänge
tagebuchimplantat. ${ }^{24}$

Reducing the semantics in this way is a process that can now be referred to as 'classical' oulipotics and was particularly mentioned in Raymond Queneau's Exercises de style, though not for translation purposes.

The same applies to another type of translation, which focuses on a numerically and lexically controlled exchange mechanism. The respective contrainte is 'NVA +7 ' and describes a substitution procedure according to which, in a given text, every noun, verb, and adjective ('NVA') is replaced by the seventh next noun, verb, or adjective in any dictionary (which is then usually specified). This contrainte, which was invented by Jean Lescure, and which Oskar Pastior made use of not only when translating into German but also when translating Baudelaire's poems from French into French (Harmonie du soir becomes Hasard du solde), ${ }^{25}$ moves along the axes of paradigm and syntagma, of

24 Pastior (2002), roher iasmin, p. 31.

25 Pastior (2002), roher iasmin, p. 18. 
selection and combination; they were described by Roman Jakobson's formalistic text concept as being structural principles of both language in general and the language of poetry. The number ' 7 ' is arbitrary, as is the selection of the parts of speech. If, according to the rule ' $x+n$,' the number ' $n$ ' were identical to the number of entries of the part of speech ' $x$ ' in a particular dictionary, the source text would encounter itself as the ' $n$ th' potentiality. ${ }^{26}$

Finally, the question: How much weight does a poem have? In any case, according to its title, the weight of Baudelaire's poem is '169,' measured in terms of an oulipotic contrainte, which Michelle Grangaud invented, and whose outcome gewichtete Gedichte she referred to as poèmes timbrés, which can be read as "mad" (in the sense of cinglés) but also as (especially harmoniously) "timbric" and not least as "depreciated," "franked" poems. These poems are franked with the arbitrary numeric of the alphabet itself: 'A $=1$, ' $\mathrm{B}=2$,' ' $\mathrm{C}=3$ ' until ' $\mathrm{Z}=26$.' Having first learnt of this contrainte in January 1998, Pastior was "electrified" "from the very beginning,"27 as he confessed to Michelle Grangaud by post. He sent "franked poems" to all kinds of friends and acquaintances by post - therefore with stamps, with timbres on them, and always in German-, outlining the respective weight of the poem's title on it. In the Baudelaire 'intonations,' he used the contrainte as a means of translation and calculated that Harmonie du soir has the number '169,' and, in turn, he generated German words and word sequences from this number. For instance, meine mikadozikaden or orangenbuchstaben or charles baudelaire du. One can hardly speak of a 'translation' in the traditional sense, and yet this traduction sous contrainte is, in some respect, the most stringent that can be thought of. For, in the act of franking, it leads to one (and perhaps the only) evident similarity between the French and the German language. Of course, both share this with many other languages: the arbitrary, yet multi- and interlingual regulatory scheme of the alphabet itself, which, in French as well as in German, ranges from A to $\mathrm{Z}$ and contains 26 letters arranged in identical linearity. The franking of poems - which, due to the postal context, not least contains a dialogical impulse that, in the first instance, addresses Baudelaire's poem-is measured by a code defined by an alphabetic order, and that does not change in the act of translation from, for example, French to German. The fact that Harmonie du

26 On this contrainte, see also Jürgen Ritte, Das Sprachspiel der Moderne. Eine Studie zur Literarästhetik Georges Perecs. Cologne: Janus, 1992, pp. 95-96.

27 Oskar Pastior, Gewichtete Gedichte. Chronologie der Materialien, with contributions by Ralph Kaufmann and Oswald Egger. Vienna-Hombroich: Das böhmische Dorf, 2006, p. 19 (letter from 1 Mar. 2000). 
soir - ' 169 ' - can be transferred to the word Letterngewicht, ${ }^{28}$ the "weight of the letters," is indeed the wittiest result of Pastior's implementation of this contrainte.

One could continue here even longer and speak of akronymakronymen, akronymakrosticha with counter-direction at the end of a line and various zopfmodulen. In the end, however, the focus should be on conclusions from Pastior's Baudelaire project from a methodological point of view.

\section{Applied Translation Research}

Any form of translation, especially of literary texts, inevitably and incessantly faces the decision as to what exactly should be translated. This problem is examined in an artistic way in Pastior's Baudelaire project. It is based on an experimental procedure that is organised in an almost mathematical-scientific manner; it defines a method, namely the segmentation by means of (the) contrainte(s), to examine the language material under changing yet deliberately chosen perspectives. It also uses a serial circuit that inscribes an argumentative structure on the literary text. As virtuoso and reflective as it may be, the ultimate refinement of the project is that it not only performs a practice of aesthetic thinking but also convinces as a literary work of art.

Translation from German by Margret Smith.

\section{Bibliography}

ADPF (L'Association pour la diffusion de la pensée française), ed., Oulipo. Paris: ADPF Publications, 2005.

Arts, Clemens, Oulipo et Tel Quel. Jeux formels et contraintes génératrices. Ridderkerk: Offsetdrukkerij Ridderprint, 1999.

Bens, Jacques, Genèse de l'Oulipo 1960-1963. Bordeaux Cedex: Castor Astral, 2005.

Brecht, Bertolt, "Die Übersetzbarkeit von Gedichten" (1935), in: Schriften zur Literatur und Kunst 2 (= Gesammelte Werke 19), ed. by Suhrkamp in cooperation with Elisabeth Hauptmann. Frankfurt am Main: Suhrkamp, 1967, p. 404.

Derrida, Jacques, "Des Tours de Babel," translated by Joseph F. Graham, in: Joseph F. Graham, ed., Difference in Translation. Ithaca, NY, London: Cornell University Press, 1985, pp. $165^{-205}$.

28 Pastior (2002), roher iasmin, p. 21. 
Ferentschik, Klaus, 'Pataphysik - Versuchung des Geistes. Die 'Pataphysik \& das Collège de 'Pataphysique: Definitionen, Dokumente, Illustrationen. Berlin: Matthes \& Seitz, 2006.

Le Tellier, Hervé, Esthétique de l'Oulipo. Bordeaux Cedex: Castor Astral, 2006.

Pastior, Oskar, "Vom geknickten Umgang mit Texten wie Personen," in: Sprache im technischen Zeitalter 86 (1983), pp. 178-183.

Pastior, Oskar, Kopfnuß Januskopf. Gedichte in Palindromen. Munich, Vienna: Hanser, 1990.

Pastior, Oskar, "Petrarca, und andere Versuchsanordnungen," in: Axel Gellhaus et al., eds., Die Genese literarischer Texte. Modelle und Analysen. Würzburg: Königshausen \& Neumann, 1994, S. 257-286.

Pastior, Oskar, "Vom Umgang in Texten," in: manuskripte 35:128 (1995), pp. 20-47.

Pastior, Oskar, o du roher iasmin. 43 intonationen zu 'Harmonie du soir' von charles baudelaire. Weil am Rhein et al.: Engeler, 2002.

Pastior, Oskar, Gewichtete Gedichte. Chronologie der Materialien, with contributions by Ralph Kaufmann and Oswald Egger. Vienna-Hombroich: Das böhmische Dorf, 2006.

Predoiu, Grazziella, Sinn-Freiheit und Sinn-Anarchie. Zum Werk Oskar Pastiors. Frankfurt am Main et al.: Peter Lang, 2004.

Reggiani, Christelle, Rhétoriques de la contrainte. Georges Perec - l'Oulipo. SaintPierre-du-Mont Cedex: Éditions InterUniversitaires, 1999.

Ritte, Jürgen, Das Sprachspiel der Moderne. Eine Studie zur Literarästhetik Georges Perecs. Cologne: Janus, 1992.

Schleypen, Uwe, Schreiben aus dem Nichts. Gegenwartsliteratur und Mathematik - das Ouvroir de littérature potentielle. Munich: Meidenbauer, 2004. 